University of Nebraska - Lincoln

DigitalCommons@University of Nebraska - Lincoln

7-13-2002

\title{
REVISION OF PARAMINOTA SCHERER (COLEOPTERA: CHRYSOMELIDAE)
}

Alexander Konstantinov

Systematic Entomology Laboratory, PSI, Agricultural Research Service, U.S. Department of Agriculture, c/o National Museum of Natural History

Follow this and additional works at: https://digitalcommons.unl.edu/usdaarsfacpub

Konstantinov, Alexander, "REVISION OF PARAMINOTA SCHERER (COLEOPTERA: CHRYSOMELIDAE)" (2002). Publications from USDA-ARS / UNL Faculty. 2290.

https://digitalcommons.unl.edu/usdaarsfacpub/2290

This Article is brought to you for free and open access by the U.S. Department of Agriculture: Agricultural Research Service, Lincoln, Nebraska at DigitalCommons@University of Nebraska - Lincoln. It has been accepted for inclusion in Publications from USDA-ARS / UNL Faculty by an authorized administrator of DigitalCommons@University of Nebraska - Lincoln. 


\title{
REVISION OF PARAMINOTA SCHERER (COLEOPTERA: CHRYSOMELIDAE)
}

\author{
Alexander Konstantinov \\ Systematic Entomology Laboratory, PSI, Agricultural Research Service, U.S. \\ Department of Agriculture, c/o National Museum of Natural History, MRC 168, \\ Washington, DC 20560
}

\begin{abstract}
Paraminota is revised and Chabriella Medvedev, 1990 and Schawalleria Medvedev, 1990 are synonymized with Paraminota. Chabriella minuta Medvedev, 1990 is synonymized with Schawalleria lamprosomoides Medvedev, 1990. A new species, P. lauribina from Nepal is described. A key to species of Paraminota and illustrations of all these taxa are provided.
\end{abstract}

Key words: Chrysomelidae, synonymy, new species, Nepal.

Paraminota was proposed by Scherer (1989) for his newly described P. minima but not without hesitation. He had made a considerable effort to place it in Minota Kutschera. Both genera occur in mountains at significant altitudes and live very close to the soil surface, sometimes in the leaf litter or in moss. Both lack hind wings and as a result have their thoracic structures significantly simplified, but Scherer concluded that Paraminota has enough unique features to justify its generic status. A second species of Paraminota was described by Döberl (1991), but upon further examination it was shown to belong to a previously unknown genus (Döberl \& Konstantinov, in press). Examination of numerous taxa described from Nepal by Medvedev $(1984,1990)$ revealed that Schawalleria Medvedev and Chabriella Medvedev are synonyms of Paraminota, and moreover Schawalleria lamprosomoides Medvedev and Chabriella minuta Medvedev are conspecific despite the fact that they were described in the same paper side by side.

Dissecting techniques and terminology for internal and external structures follow Konstantinov (1998). Measurements were taken for all available specimens and the mean was used in the descriptions and key.

GENUS PARAMINOTA SCHERER

(Figs. 1-36)

Paraminota Scherer, 1989:52 (Type species Paraminota minima Scherer, 1989:53, by original designation).

Chabriella Medvedev, 1990:34 (Type species Chabriella minuta Medvedev, 1990: 34 by original designation). New synonym.

Schawalleria Medvedev, 1990:35 (Type species Schawalleria lamprosomoides Medvedev, 1990:35, by original designation). New synonym.

Description. Body small, length $1.11-1.50 \mathrm{~mm}$, width $0.73-1.02 \mathrm{~mm}$, ovoid (Fig. 1), relatively flat in lateral view (Fig. 20). Color black, brown or dark brown with lighter appendages. 

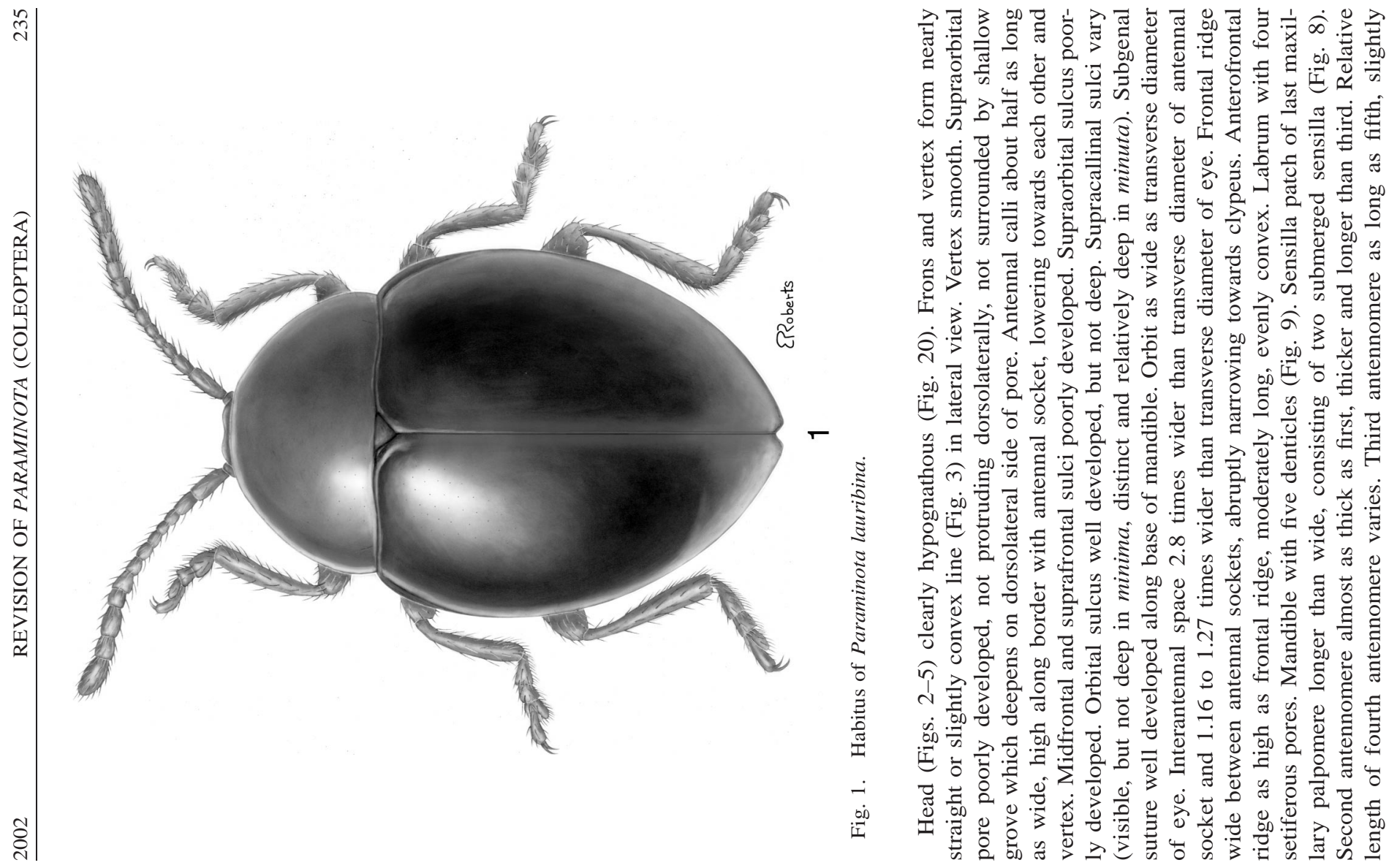

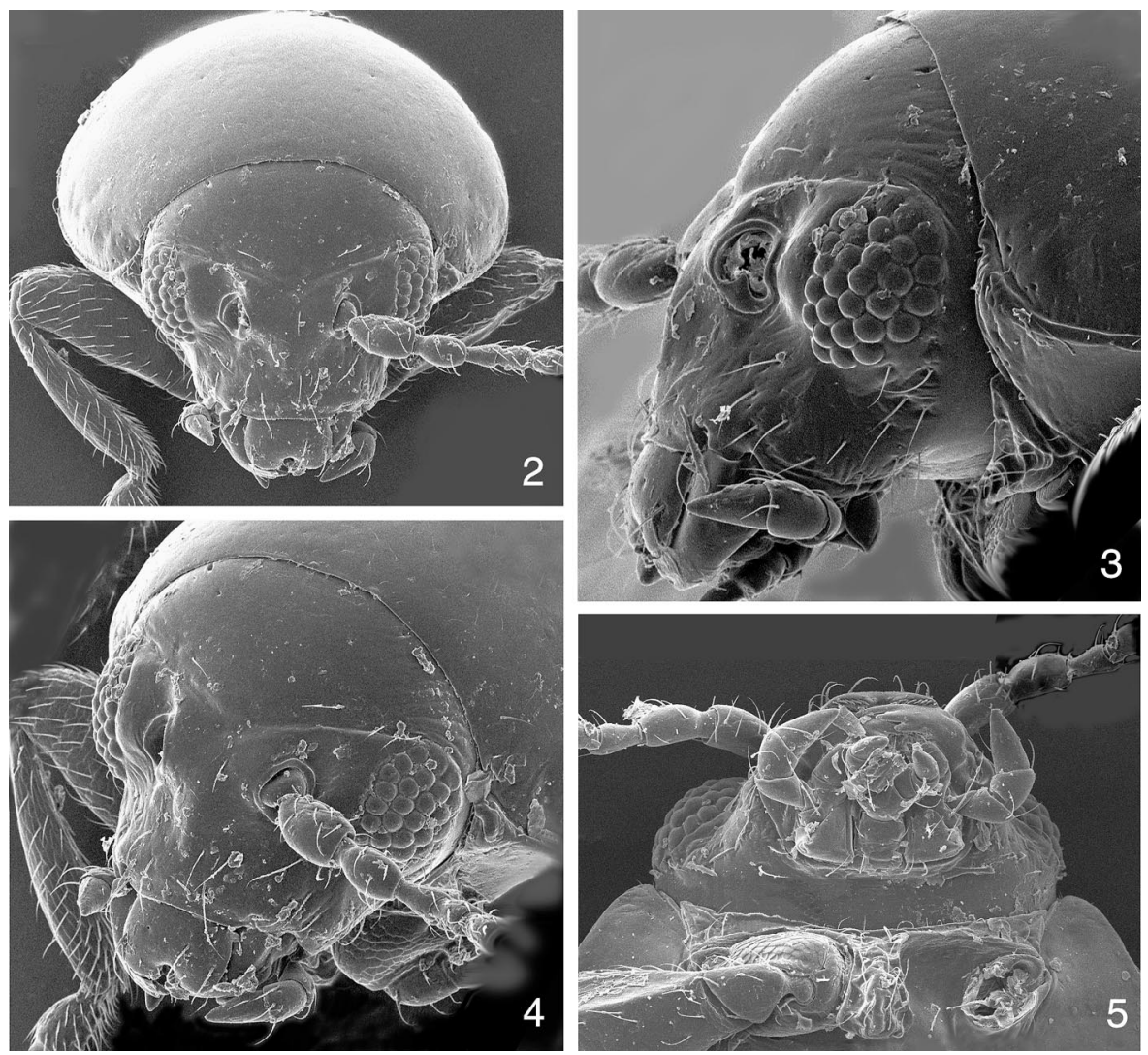

Figs. 2-5. Head of Paraminota lauribina. 2, frontal view. 3, lateral view. 4, frontolateral view. 5, ventral view.

longer than sixth (Figs. 6,7). Antennomere 8 much shorter than 7 and 9 separately. Antennomere 10 nearly as long as wide.

Pronotum (Fig. 1) 1.35 to 1.54 times wider than long, with two poorly developed longitudinal impressions. Lateral sides nearly straight and parallel to each other at basal one third, converging gradually in apical two thirds. Anterolateral callosity well developed, variable in shape. Setiferous pore on anterolateral callosity poorly developed, seta short (Fig. 17). Posterolateral callosity not protruding (Figs. 17, 18). Anterior coxal cavity open. Intercoxal prosternal process narrow in middle widening apically, extending beyond coxa (Fig. 18). Distance between proximal part of prosternum to coxal cavity more than 7 times shorter than to end of intercoxal prosternal process (Fig. 18).

Elytron without humeral callus, with maximum width at basal one third, lacking striae. Elytral apex concave with acute denticle at suture. Epipleura nearly vertical, not reaching sutural margin of elytron (Figs. 10, 20). Lateral margin of elytron completely visible from above only near pronotum. Mesosternum including inter- 

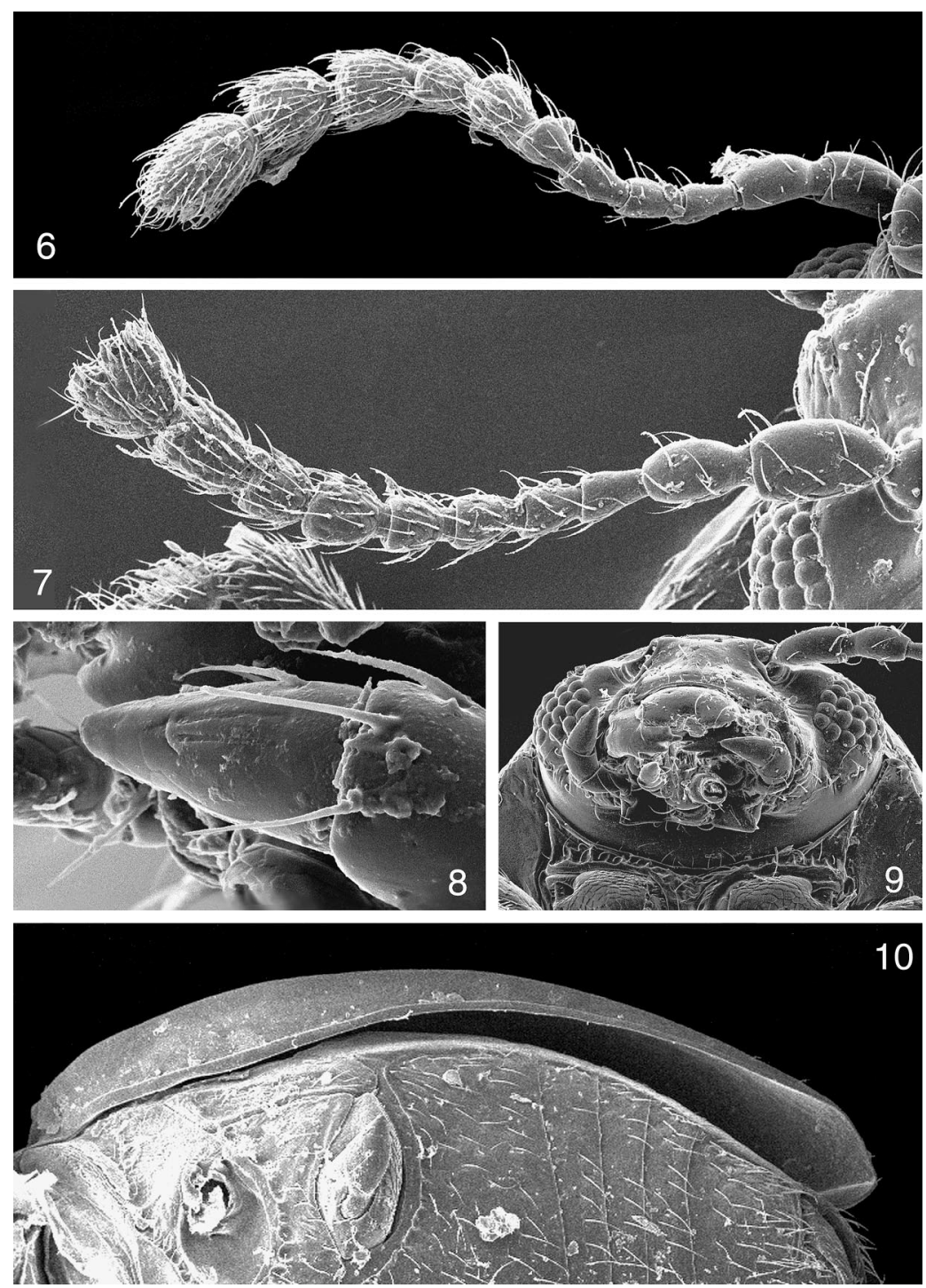

Figs. 6-10. Paraminota lauribina. 6, antenna \$. 7, antenna +.8 , apical palpomere of maxillary palpus. 9 , mouth parts. 10 , ventral side of body with legs removed.

coxal mesosternal process slightly longer than longitudinal diameter of mesocoxal cavity (Fig. 19). Mesosternal intercoxal process wider than prosternal intercoxal process, concave on top. Metasternum as short as mesosternum (Fig. 19).

Pro- and mesotibiae with tiny apical spine, visible only under scanning electron microscope. First protarsomere in male wider than in female, with oval depression 

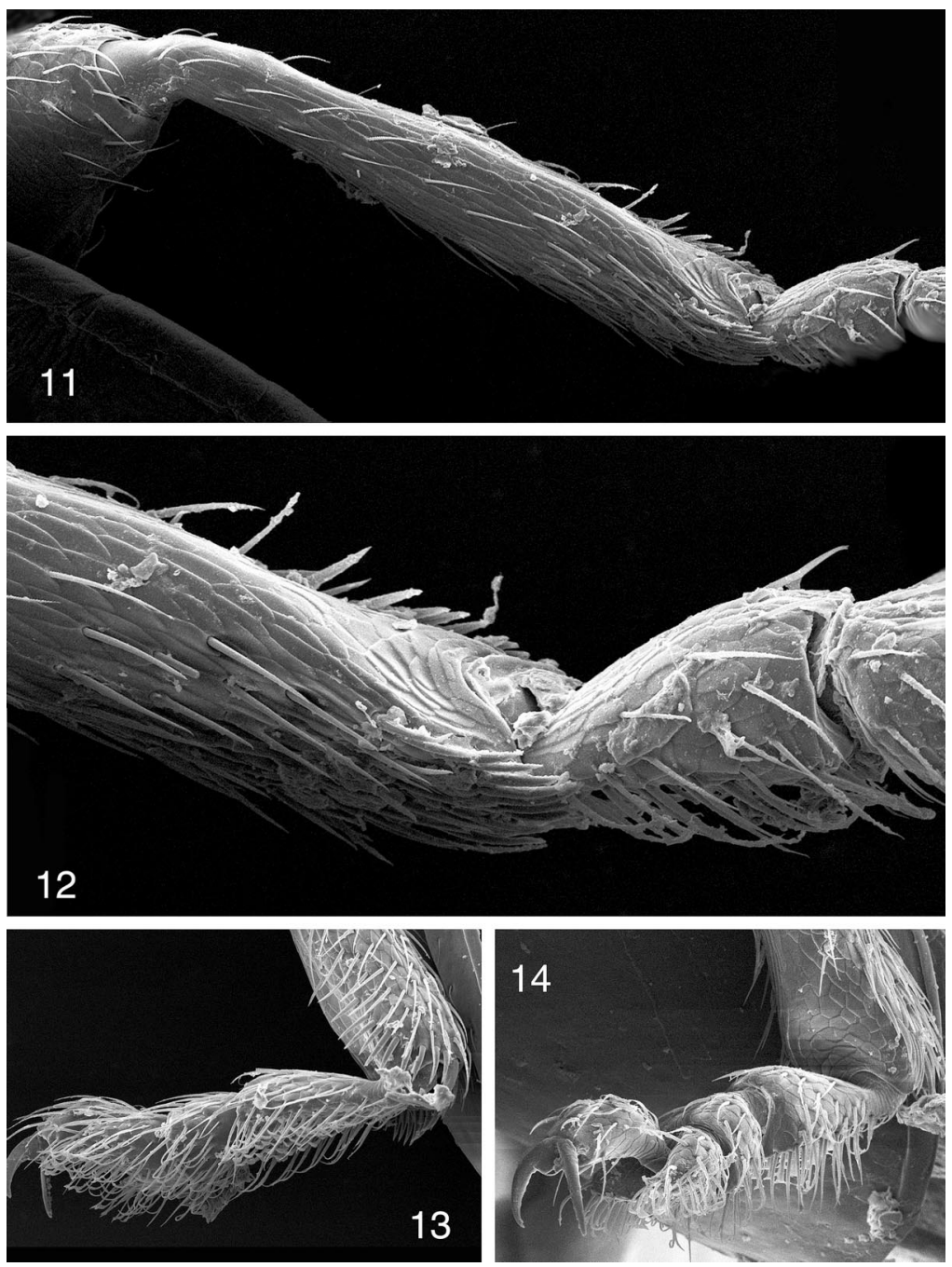

Figs. 11-14. Legs of Paraminota lauribina. 11 and 12, metatibia. 13 and 14, metatarsus.

ventrally covered with mushroom shaped setae (Figs. 15, 16). Metatibia (Figs. 11, 12) nearly cylindrical, apical $1 / 6$ flattened, without callosity. Apical spur shorter than tarsal claw. First metatarsomere flattened ventrally, 4.6 times shorter than metatibia, ventral side covered with short feather-shaped setae, different from setae on dorsal side (Fig. 13). Third metatarsomere deeply bilobed (Fig. 14).

Abdomen with five distinct sternites (Figs. 10, 26, 31, 36). Apical abdominal sternite widely triangular, lateral sides converging, with two appendages basally. Tergite one of female evenly covered with long setae, with groove in middle (Figs. $24,30,35)$. 

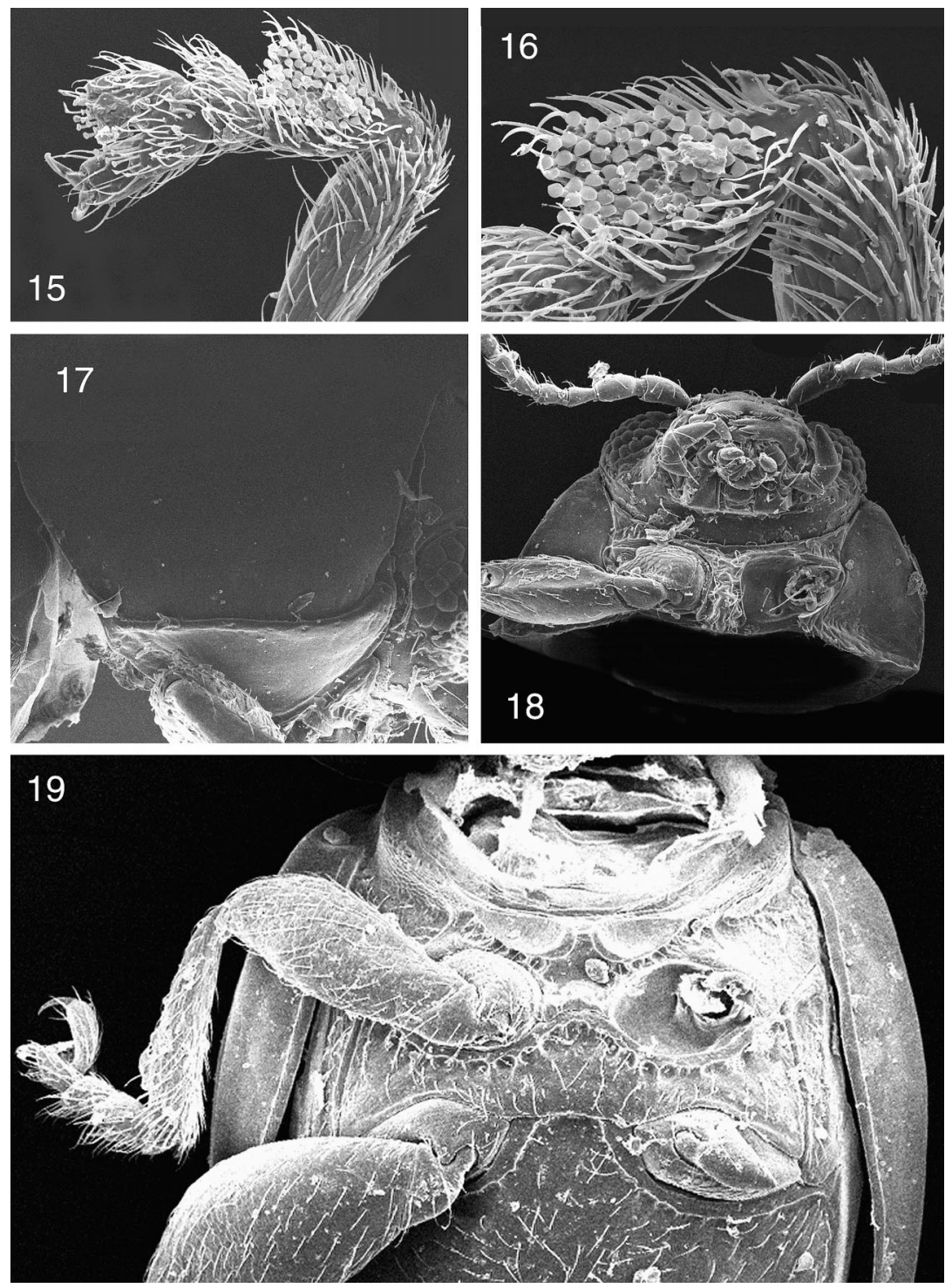

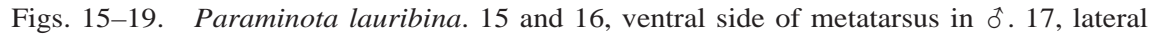
side of pronotum. 18, ventral side of prothorax. 19, ventral side of meso- and metasterna.

Spermatheca (Figs. 23, 28, 34) with receptacle longer and wider than pump. Receptacle with internal side and external side convex. Receptacle with variously developed hump near base of pump. Pump makes acute angle with receptacle, swollen at apex and at base of horizontal part. Duct without coils, makes loop away from receptacle. Tignum (Figs. 27, 29, 33) straight, slightly widening anteriorly, posterior 


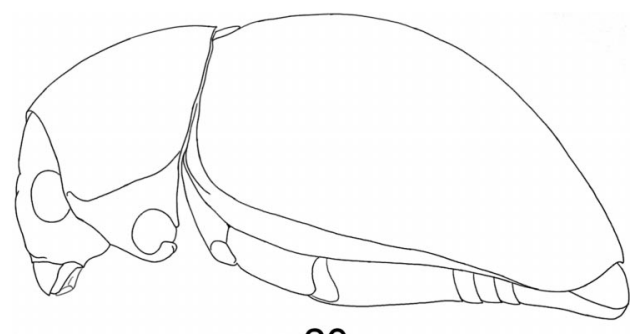

20

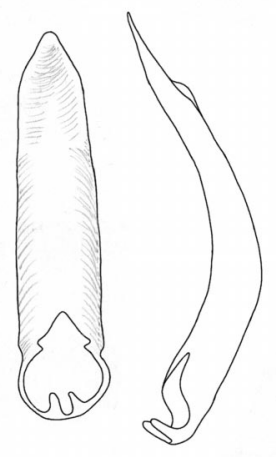

21

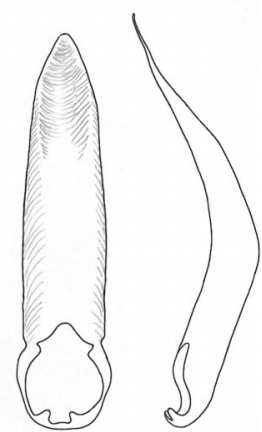

22

Figs. 20-22. Details of Paraminota. 20, lateral view of P. lauribina. 21, ventral and lateral view of median lobe of aedeagus of $P$. minima. 22, ventral and lateral view of median lobe of aedeagus of $P$. lauribina.

sclerotization straight. Vaginal palpus (Figs. 25, 29, 32) with anterior sclerotization almost as wide as posterior.

Median lobe of aedeagus (Figs. 21, 22) relatively robust, simple in shape, slightly convex in lateral view, with shallow impression ventrally at apex, without membranous window. Proximal part of basal opening with two closely situated long denticles.

Discussion. I compared the holotype of Chabriella minuta Medvedev with the paratypes of Paraminota minima Scherer and found them extremely similar (including such a key character as procoxal cavity). The original description of Paraminota (Scherer, 1989) stated that the procoxal cavities are closed, however in parenthesis Scherer (1989:52) added "hardly visible." Indeed it is difficult to examine the procoxal cavities of dry specimens, because they tend to bend the pronotum down, so that the prosternum is situated very close to the mesosternum. However, in dissected specimens it is absolutely clear that the procoxal cavities are far from being closed. In the original description of Chabriella, Medvedev (1990) mentioned the open procoxal cavities as the only feature of the new genus distinctive from Paraminota. Medvedev (1990) also compared Chabriella with the very distantly related Chabria Jacoby and concluded that they can be separated by the presence of "longitudinal grooves at base" of the pronotum in Chabriella, but the same grooves occur in 

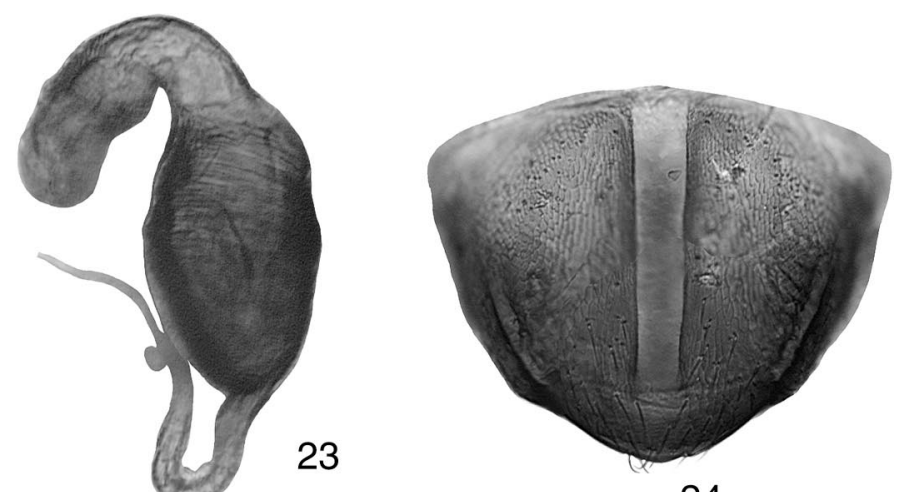

24

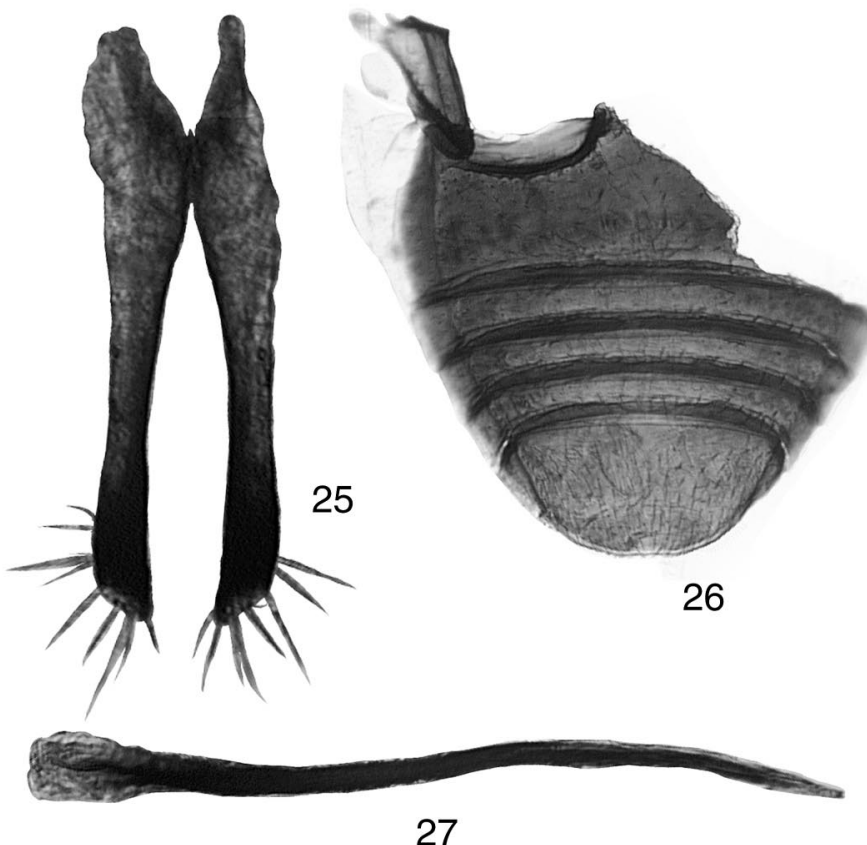

Figs. 23-27. Female genitalia of Paraminota lamprosomoides. 23, spermatheca. 24, apical abdominal tergite. 25 , vaginal palpi. 26, abdominal sternites. 27 , tignum.

Paraminota. In all other features Chabriella is very similar to Paraminota. Based on the above I hereby synonymize Chabriella with Paraminota.

I also compared the holotypes of Chabriella minuta and Schawalleria lamprosomoides Medvedev and found that they are not only congeneric, but also conspecific. Medvedev (1990) did not compare Schawalleria with Chabriella nor Paraminota despite their obvious similarity. Instead he compared Schawalleria with such distantly related genera as Chabria and Amphimeloides Jacoby and proposed to distin- 

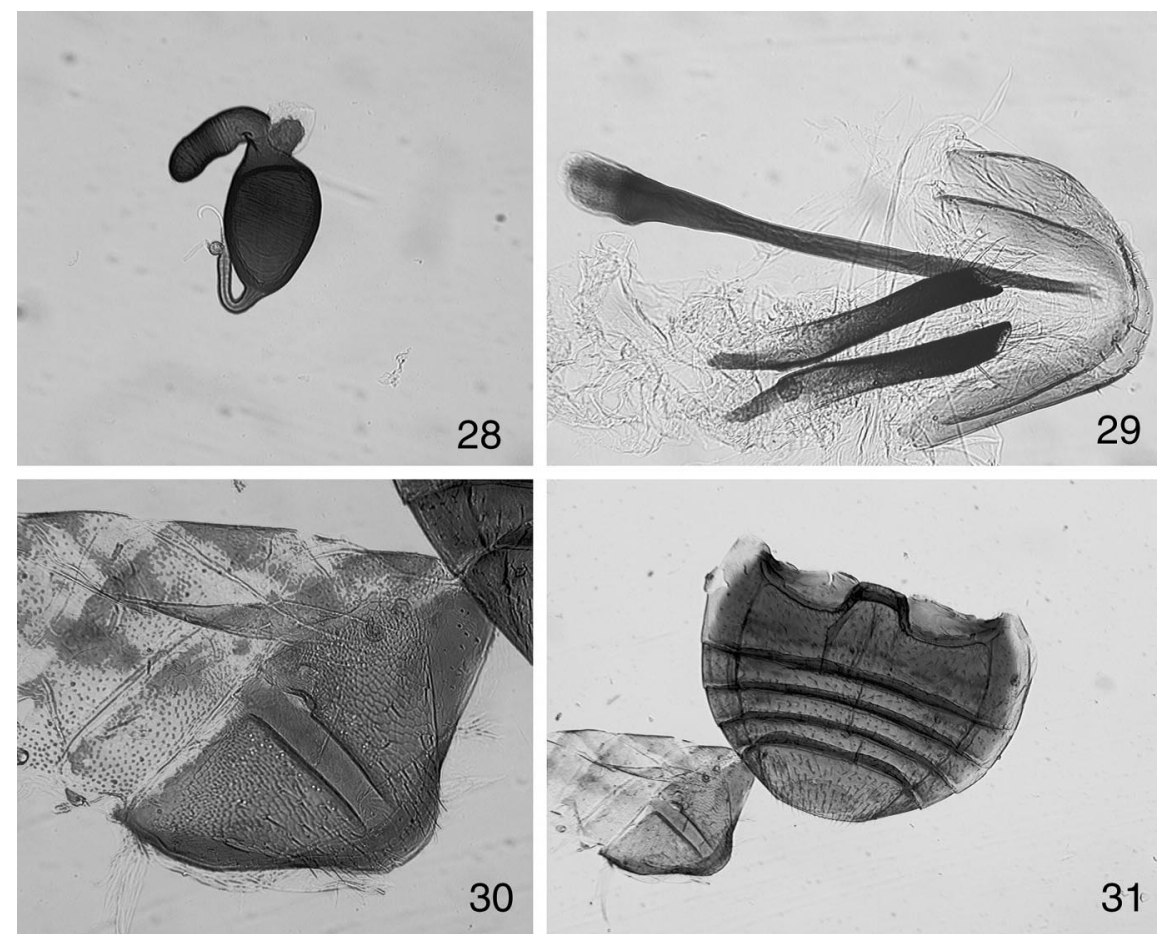

Figs. 28-31. Female genitalia of Paraminota minima. 28, spermatheca. 29, vaginal palpi and tignum. 30, apical abdominal tergite. 31, abdominal sternites.

guish it by the "prothorax less transverse, upper surface impunctate and, especially, 8th antennal segment small and globular..." Of these three characters only the latter has some significance for distinguishing genera, however this "small" antennomere is not a unique feature of Schawalleria. It occurs in the well known European flea beetle Mniophila muscorum Koch and in the type species of Paraminota and Chabriella. That leaves no characters to separate Schawalleria, Chabriella, and Paraminota and hence they are synonymized.

\section{Paraminota lamprosomoides (Medvedev), new combination}

(Figs. 23-27)

Schawalleria lamprosomoides Medvedev, 1990:35 (Type locality: Nepal, Taplejung. Holotype (SMNS), examined).

Chabriella minuta Medvedev, 1990:34 (Type locality: Nepal, Taplejung. Holotype (SMNS), examined). New synonym.

Description. Body unicolorous, piceous. Length $1.5 \mathrm{~mm}$. Body length/width ratio 1.48. Supracallinal sulci very distinct and relatively deep. Interantennal space 2.8 times wider than transverse diameter of antennal socket and 1.27 times wider than transverse diameter of eye. Second antennomere of female 1.64 times longer than 


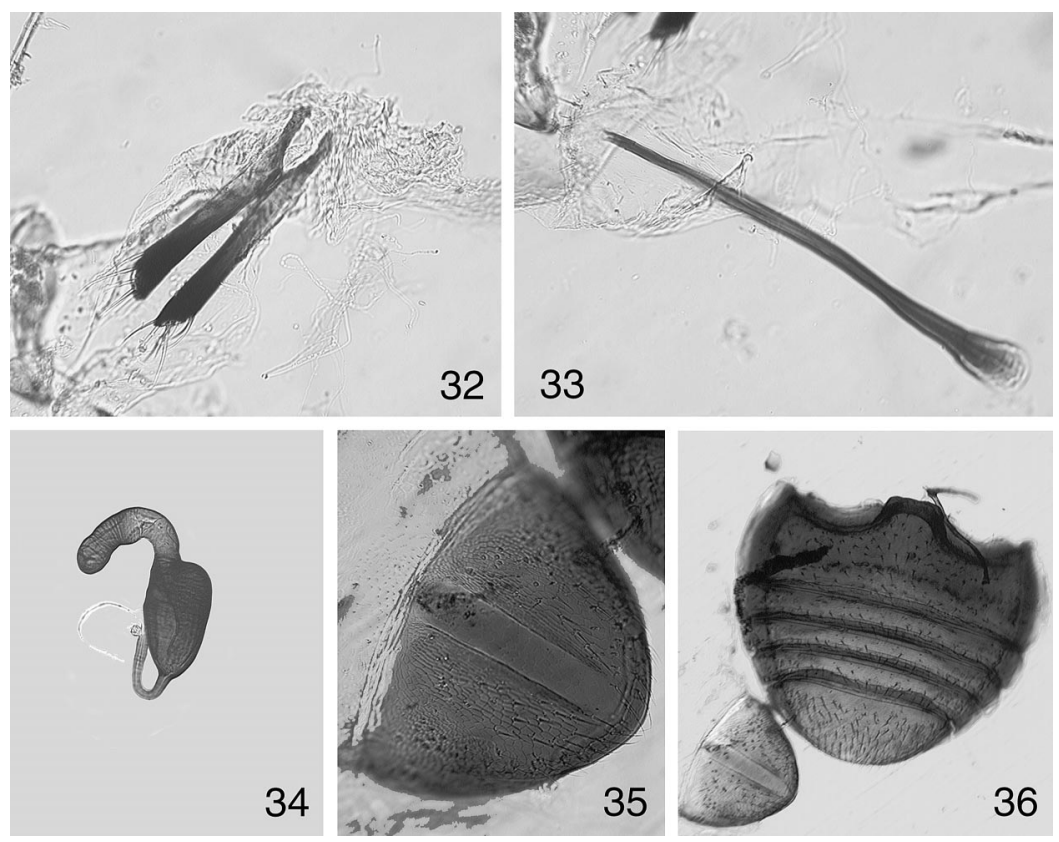

Figs. 32-36. Female genitalia of Paraminota lauribina. 32, vaginal palpi. 33, tignum. 34, spermatheca. 35, apical abdominal tergite. 36, abdominal sternites.

third and 0.82 times as long as first. Fourth antennomere shorter than third and fifth separately. Pronotum width/length ratio 1.54 . Anterolateral callosity slightly protruding anteriorly.

Apical abdominal tergite is 1.05 times wider than long (Fig. 24). Apical abdominal sternite 1.79 wider than long (Fig. 26).

Spermatheca (Fig. 23) with receptacle longer than pump. Receptacle 1.73 times longer than wide, with maximum width near middle. Internal side more convex than external side. External side of receptacle with little hump near base of pump. Pump 2.1 times longer than wide, rounded at apex. Horizontal part of pump much longer than vertical. Duct without coils, making relatively long loop away from receptacle, pointing in direction of receptacle. Internal and external sides of loop parallel. Tignum (Fig. 27) slightly curved, narrowing posteriorly, widening anteriorly. Vaginal palpus (Fig. 25) with membranous part in middle longer than sclerotized part anteriorly and posteriorly. Posterior sclerotization nearly as long as anterior. Lateral margin not parallel to medial, forming well developed angle at apex.

Discussion. Paraminota lamprosomoides can be separated from the other two known species of Paraminota based on the characters given in the key below. Examination of the holotypes of Schawalleria lamprosomoides and Chabriella minuta, which were collected from the same area and similar altitude during the same month, revealed they are undoubtedly conspecific. Schawalleria lamprosomoides is regarded 
as the senior synonym, the holotype of $C$. minuta was dissected by Medvedev and lacks all the contents of the abdomen including the female genitalia.

Type material examined. Schawalleria lamprosomoides. Holotype, + . Labels: 1) Nepal- Expeditionen Jochen Martens; 2) Holotypus; 3) 359 Taplejung Distr., pasture Lassetham NW Yamputhin, 3,300-3,500 m, mature Abies-Rhododendron-Juniperus forest, 6-9 May 1988, J. Martens \& W. Schawaller leg.; 4) Schawalleria lamprosomoides L. N. Medvedev det. 1989; Paraminota lamprosomoides (Medvedev), det. A. Konstantinov (SMNS).

Chabriella minuta. Holotype, + . Labels: 1) Nepal-Expeditionen Jochen Martens; 2) 362 Taplejung Distr., upper Simbua Khola Valley, near Yalung, 3,450-3,700 m, Abies-Rhododendron-Juniperus forest, 15 May 1988, J. Martens \& W. Schawaller leg.; 3) Holotypus; 4) Chabriella minuta m. L. N. Medvedev det. 1989; 5) Paraminota lamprosomoides (Medvedev) det. A. Konstantinov 2000 (SMNS).

\section{Paraminota lauribina, new species}

(Figs. 1-20, 22, 32-36)

Description. Head and pronotum piceous, lighter than elytron. Length 1.29-1.34 $\mathrm{mm}$. Body length/width ratio 1.62. Supracallinal sulci distinct. Interantennal space 2.8 times wider than transverse diameter of antennal socket and 1.18 times wider than transverse diameter of eye. Second antennomere of female 1.10-1.30 times longer than third and approximately 0.50 times as long as first. In males second antennomere 1.58-1.63 times longer than third and approximately 0.56 times as long as first. Fourth antennomere as long as third, slightly shorter than fifth. Pronotum 1.43 times wider than long. Anterolateral callosity not protruding anteriorly.

Apical abdominal tergite is 1.17 times wider than long (Fig. 35). Apical abdominal sternite 2.21 wider than long (Fig. 36).

Spermatheca (Fig. 34) with receptacle longer than pump. Receptacle 1.83 times longer than wide, with maximum width above middle. Internal side slightly more convex than external side. External side of receptacle with large hump near base of pump. Pump 2.01 times longer than wide, rounded at apex. Horizontal part of pump longer than vertical. Duct without coils, making loop away from receptacle, pointing in direction of receptacle. Internal and external sides of loop nearly parallel. Tignum (Fig. 33) slightly curved, narrowing posteriorly, widening anteriorly. Vaginal palpus (Fig. 32) with membranous part in middle much shorter than sclerotized part anteriorly and posteriorly. Posterior sclerotization much longer than anterior. Lateral margin not parallel to medial, forming well developed angle at apex.

Median lobe (Fig. 22) apically thin in lateral view, with well developed impression ventrally. Proximal part of basal opening with two short denticles.

Discussion. Paraminota lauribina can be separated from the other two known species of Paraminota based on the characters given in the key below. It is generally more similar to $P$. minima than to $P$. lamprosomoides.

Etymology. The specific epithet is a noun in apposition based on the type locality. Types. Holotype, ô. Labels: 1) Nepal. Lantang Nat. Park, Lauribina $28^{\circ} 05.25^{\prime} \mathrm{N}$ $85^{\circ} 23.37^{\prime} \mathrm{E}$, 4.V.00, 3,850 m, leg. Konstantinov, Lingafelter, Volkovitsh; 2) Holotype Paraminota lauribina des. A. Konstantinov, 2001 (USNM). Paratypes: 4 o and 8 + , same labels as holotype (1 SMNS, 1 NARN, 5 USNM); same labels as holotype except “3,500 m” (5 USNM). 


\section{Paraminota minima Scherer}

(Figs. 21, 28-31)

Paraminota minima Scherer, 1989:53 (Type locality: Nepal, Prov. Bagmati, Yangri Ridge. Holotype and paratypes (CNCI), paratypes examined).

Description. Head and pronotum piceous, slightly lighter than elytron. Length 1.31$1.42 \mathrm{~mm}$. Body length/width ratio 1.61. Supracallinal sulci visible, but not deep. Interantennal space 2.8 times wider than transverse diameter of antennal socket and 1.16 times wider than transverse diameter of eye. Second antennomere of female $1.10-1.30$ times longer than third and approximately 0.50 times as long as first. In males second antennomere 1.61-1.66 times longer than third and approximately 0.62 times as long as first. Fourth antennomere nearly as long as third, slightly shorter than fifth. Pronotum 1.35 to 1.52 times wider than long. Anterolateral callosity not protruding anteriorly.

Apical abdominal tergite is 1.34 times wider than long (Fig. 30). Apical abdominal sternite 2.18 wider than long (Fig. 31).

Spermatheca (Fig. 28) with receptacle longer than pump. Receptacle 1.14 times longer than wide, with maximum width above middle. Internal side more convex than external side. External side of receptacle with hump near base of pump. Pump 2.57 times longer than wide, rounded at apex. Horizontal part of pump much longer than vertical. Duct without coils, making loop away from receptacle, points in direction of receptacle. Internal and external sides of loop not parallel. Tignum (Fig. 29) straight, narrowing posteriorly, widening anteriorly. Vaginal palpus (Fig. 29) with membranous part in middle much shorter than sclerotized part anteriorly and posteriorly. Posterior sclerotization much longer than anterior. Lateral margin not parallel to medial, forming well developed angle to apex.

Median lobe (Fig. 21) apically thick in lateral view, with ill developed impression ventrally. Proximal part of basal opening with two long denticles.

Discussion. Paraminota minima is more similar to P. lauribina than to P. lamprosomoides in the relative length of the basal antennomeres and length of the longitudinal impression of pronotum. These species can be separated from each other based on the characters given in the key below.

Type material examined. Paratypes: 1 ô, 1 . Labels: 1) Nepal, Prov. Bagmati, Yangri Ridge, 4,350 m, 21.IV.81 leg. Löbl \& Smetana; 2) Paratype Paraminota minima n. sp. Dr. G. Scherer, 1987; 3) Paratype CNC No 20742 (CNCI).

\section{KEY TO SPECIES OF PARAMINOTA}

1. Longitudinal impression on base of pronotum nearly as long as anterolateral callosity. Second antennomere of female 1.64 times longer than third and 0.82 as long as first . . . . . . . . . . . . . . . . P. lamprosomoides (Medvedev)

- Longitudinal impression on base of pronotum shorter than anterolateral callosity. Second antennomere of female 1.10-1.30 times longer than third and approximately

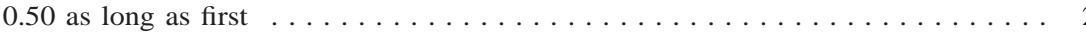

2(1). Apical abdominal tergite 1.34 times wider than long (Fig. 30). Apical abdominal sternite 2.18 wider than long (Fig. 31). External side of receptacle with hump near base of pump. Pump 2.57 times longer than wide. Internal and external sides of spermathecal loop not parallel. Median lobe (Fig. 21) apically thick in lateral view, 
with ill developed impression ventrally. Proximal part of basal opening with two

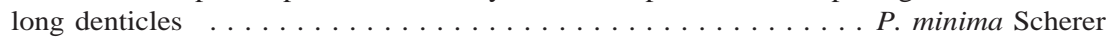

- Apical abdominal tergite 1.17 times wider than long (Fig. 35). Apical abdominal sternite 2.21 wider than long (Fig. 36). External side of receptacle with large hump near base of pump. Pump 2.01 times longer than wide. Internal and external sides of spermathecal loop nearly parallel. Median lobe (Fig. 22) apically thin in lateral view, with well developed impression ventrally. Proximal part of basal opening with two short denticles .................... lauribina $\mathrm{n}$. sp.

\section{ACKNOWLEDGMENTS}

I thank L. LeSage, Canadian National Collection, Ottawa, Canada (CNCI) and W. Schawaller, Staatliches Museum fur Naturkunde, Stuttgart, Germany (SMNS) for the opportunity to study material in their care. The other depositories of the material are abbreviated as follows: National Agricultural Research Council, Kathmandu, Nepal (NARN); National Museum of Natural History, Smithsonian Institution, Washington, D.C. (USNM). I am also grateful to D. Furth (Department of Systematic Biology, Smithsonian Institution), A. L. Norrbom, and M. A. Solis (Systematic Entomology Laboratory, Washington, D.C.) for reviewing this manuscript and providing valuable suggestions. D. Manandhar (NARN) provided assistance during my collecting trip in Nepal. The habitus illustration of Paraminota lauribina is the work of E. Roberts (Systematic Entomology Laboratory, Washington, D.C.).

\section{LITERATURE CITED}

Döberl, M. 1991. Alticinae aus Nepal. Revue Suisse Zoologique, 98:613-635.

Döberl, M. and A. Konstantinov. In press. A new genus of flea beetles from Nepal (Coleoptera: Chrysomelidae). Coleopterists Bulletin.

Konstantinov, A. S. 1998. Revision of the Palearctic species of Aphthona Chevrolat and cladistic classification of the Aphthonini (Coleoptera: Chrysomelidae: Alticinae). Memoirs on Entomology, International, Associated Publishers, Gainesville, 429 pp.

Medvedev, L. N. 1984. Chrysomelidae from the Nepal Himalayas. 1. Alticinae (Insecta: Coleoptera). Senckenbergiana Biologica, 65(1-2):46-63.

Medvedev, L. N. 1990. Chrysomelidae from the Nepal Himalayas, II (Insecta: Coleoptera). Stuttgarter Beiträge zur Naturkunde, Serie A (Biologie), 453:1-46.

Scherer, G. 1989. Ground living flea beetles from the Himalayas (Coleoptera, Chrysomelidae, Alticinae). Spixiana, 12(1):31-55.

Received 15 April 2002; accepted 13 July 2002. 